\title{
Safety of nanomaterials
}

\author{
H. Foth · J. D. Stewart • T. Gebel · H. M. Bolt
}

Published online: 26 June 2012

(C) Springer-Verlag 2012

Nanotechnology represents one of the key technologies of the twenty-first century and includes all methods that allow production, and analysis of objects sized between one and $100 \mathrm{~nm}$. A large number of nanomaterials and consumer products are already used, such as paints, car tyres, tennis rackets, textiles and sunscreens. Technologically more important than use of nanomaterials in consumer products are applications in electronics, construction materials or coatings. It is expected moreover that in some areas, nanotechnologies will bring large social benefits, as with pharmaceuticals, medical technology and water purification. There are also hopes that nanotechnologies will make an important contribution to protecting the environment.

While great expectations are placed in the potential of nanotechnologies, there are also increasing warnings of possible risks due to insufficient knowledge about the effects of these technologies on the human organism and the environment (SRU 2011a). Available knowledge on the risks of nanoparticles and nanofibres varies in extent, and

\section{H. Foth $(\square)$}

Martin-Luther-Universität Halle-Wittenberg,

Franzosenweg 1 a, 06097 Halle (Saale), Germany

e-mail: heidi.foth@medizin.uni-halle.de

\section{J. D. Stewart · H. M. Bolt}

Leibniz Centre for Occupational Working Environment and

Human Factors, Ardey Strasse 67, 44139 Dortmund, Germany

e-mail: stewart@ifado.de

H. M. Bolt

e-mail: Bolt@ifado.de

T. Gebel

Federal Institute for Occupational Safety and Health,

Friedrich-Henkel Weg 1-25, PO Box 170202,

44061 Dortmund, Germany

e-mail: Gebel.thomas@baua.bund.de in many cases, notably regarding exposures, there are major gaps in that knowledge. In recent years, the number of contributions about nanotechnology submitted to our journal has massively increased (Gibson et al. 2011; Truong et al. 2011; Heng et al. 2011a; Jeong et al. 2010). Cutting-edge topics in our journal are uptake and biodistribution (Zhang et al. 2011; Gehrke et al. 2011; Xie et al. 2010), inflammation and apoptosis (Heng et al. 2011b; Lee et al. 2011; Marano et al. 2011) as well as oxidative stress and genotoxicity (Foldbjerg et al. 2011; Clift et al. 2011; Kim et al. 2011) induced by nanoparticles.

From the research findings to date, there is no proof of adverse changes in the environment or in human health as a result of the manufacture and use of nanoparticles and nanofibres currently on the market. This cannot be taken as an all-clear, however, because understanding of the risks of these materials remains very incomplete and some research findings raise substantial concerns. A distinction can be made between materials that have been on the market for some time, where there are already toxicology and exposure studies, and new materials where hardly anything is known about toxicological profiles and environmental fate. Public debate about the opportunities and risks of nanotechnology has started (SRU 2011b) and need to be addressed by toxicologist.

There are already initial efforts at classifying nanoparticles and nanofibres into risk categories. Such materials should nonetheless be subjected case by case to sciencebased risk assessment for time being, as too much information on risk-determining characteristics is lacking and even very small differences, such as a coating, can critically alter a material's effects in biological systems. A crucial property for science-based risk assessment is the ability of nanoparticles and nanofibres to reach parts of organisms and cells where comparable materials at a larger 
scale are not encountered. Very little is known to date, however, about the particle characteristics that determine biopersistence within cells or organisms and may be crucial for adaptive responses or toxic reactions. Some materials such as zinc oxide and silver nanoparticles are able in physiological media to release ions that interact with cell components and thus induce effects. In comparative studies carried out so far, some of these materials had a similar effect to comparable, soluble materials, which speaks in favour of the hypothesis that ions released by the nanoparticles concerned determine their toxicity (SRU 2011a).

However, despite an enormous amount of work invested into nano research, a number of key questions have still not been answered sufficiently: Do nanoparticles have qualitatively different effects resulting from their physicochemical properties-in other words: Is nanotoxicology more than the toxicology of the ions released from particles? Can nanoparticles accumulate in cells and organs? If yes do they reach thresholds critical for toxicity under relevant exposure scenarios? Do nanoparticles cause cardiovascular diseases as suggested by some epidemiological studies? Can certain types of nanoparticles be subsumed into classes to facilitate risk evaluation?

Considering the high relevance and topicality of nanotoxicology, the editors are pleased to present this special issue regarding the safety aspects of nanomaterials.

\section{References}

Clift MJD, Gehr P, Rothen-Rutishauser B (2011) Nanotoxicology: a persepective, discussion of whether or not in vitro testing is a valid alternative. Arch Toxicol 85:723-731 (review)

Foldbjerg R, Dang DA, Autrup H (2011) Cytotoxicity and genotoxicity of silver nanoparticles in the human lung cancer cell line, A549. Arch Toxicol 85(7):743-750

Gehrke H, Pelka J, Hartinger CG, Blank H, Bleimund F, Schneider R, Gerthsen D, Bräse S, Crone M, Türk M, Marko D (2011) Platinum nanoparticles and their cellular uptake and DNA platination at non-cytotoxic concentrations. Arch Toxicol 85(7): 799-812
Gibson N, Holzwarth U, Abbas K, Simonelli F, Kozempel J, Cydzik I, Cotogno G, Bulgheroni A, Gilliland D, Ponti J, Franchini F, Marmorato P, Stamm H, Kreyling W, Wenk A, SemmlerBehnke M, Buono S, Maciocco L, Burgio N (2011) Radiolabelling of engineered nanoparticles for in vitro and in vivo tracing applications using cyclotron accelerators. Arch Toxicol 85(7): 751-773 (review)

Heng BC, Zhao X, Xiong S, Ng KW, Boey FY, Loo JS (2011a) Cytotoxicity of zinc oxide ( $\mathrm{ZnO})$ nanoparticles is influenced by cell density and culture format. Arch Toxicol 85(6):695-704

Heng BC, Zhao X, Tan EC, Khamis N, Assodani A, Xiong S, Ruedl C, Ng KW, Loo JS (2011b) Evaluation of the cytotoxic and inflammatory potential of differentially shaped zinc oxide nanoparticles. Arch Toxicol 85(12):1517-1528

Jeong GN, Jo UB, Ryu HY, Kim YS, Song KS, Yu IJ (2010) Histochemical study of intestinal mucins after administration of silver nanoparticles in Sprague-Dawley rats. Arch Toxicol 84(1): 63-69

Kim JS, Lee K, Lee YH, Cho HS, Kim KH, Choi KH, Lee SH, Song KS, Kang CS, Yu IJ (2011) Aspect ratio has no effect on genotoxicity of multi-wall carbon nanotubes. Arch Toxicol 85(7): 775-786

Lee YS, Kim DW, Lee YH, Oh JH, Yoon S, Choi MS, Lee SK, Kim JW, Lee K, Song CW (2011) Silver nanoparticles induce apoptosis and $\mathrm{G} 2 / \mathrm{M}$ arrest via $\mathrm{PKC} \zeta$-dependent signaling in A549 lung cells. Arch Toxicol 85(12):1529-1540

Marano F, Hussain S, Rodrigues-Lima F, Baeza-Squiban A, Boland S (2011) Nanoparticles: molecular targets and cell signalling. Arch Toxicol 85(7):733-741 (review)

SRU (German Advisory Council on the Environment) Precautionary Strategies for managing nanomaterials, Chapter 7 Conclusions and recommendations (2011b), http://www.umweltrat.de/Shared Docs/Downloads/EN/02_Special_Reports/2011_08_Precautionary_ Strategies_for_managing_Nanomaterials_chapter07.html

SRU (German Advisory Council on the Environment) Vorsorgestrategien für Nanomaterialien (2011a), Sondergutachten ISBN 978-3-503-13833-3, Erich Schmidt Verlag

Truong L, Moody IS, Stankus DP, Nason JA, Lonergan MC, Tanguay RL (2011) Differential stability of lead sulfide nanoparticles influences biological responses in embryonic zebrafish. Arch Toxicol 85(7):787-798

Xie G, Sun J, Zhong G, Shi L, Zhang D (2010) Biodistribution and toxicity of intravenously administered silica nanoparticles in mice. Arch Toxicol 84(3):183-190

Zhang M, Li J, Xing G, He R, Li W, Song Y, Guo H (2011) Variation in the internalization of differently sized nanoparticles induces different DNA-damaging effects on a macrophage cell line. Arch Toxicol 85(12):1575-1588 